\title{
Venison into the 21st Century
}

\author{
M. MOYES \\ Venison Marketing Manager, Deer Industry New Zealand
}

\section{Introduction}

The marketing of venison in the $21^{\text {st }}$ century is a huge topic with many and varied challenges for the industry as a whole.

Firstly this paper will consider some of the consumer trends that are developing that will affect venison marketing in the future, namely, health, convenience and more restaurant dining.

Secondly it will look at tomorrow's chef - what will their role will be in the future? and what are the implications for venison? How will tomorrow's mar kets look, how and where will venison be sold?

Finally this paper considers some of the issues we need to be conscious of if we are to maintain our privileged position as a premium product.

\section{Consumer trends}

\section{Health}

Consumers are demanding more from the food they eat; there is more information on food labelling and a growing awareness of health issues (although conversely we have soaring obesity problems). This collective obsession with health is seen everywhere; gyms, the dieting industry now worth $\$ 80$ billion, exercise videos sold in supermarkets, stores and restaurant chains designed specifically to cater to the health conscious consumerabsolutely everywhere.

A number of buzzwords related to health and food have arisen. Some common ones familiar in the media are "designer foods", "nutraceuticals", "pharmafoods" and "functional foods".

The latter, functional foods are described as "foods with benefits beyond the basic nutritional benefits" (Nutrition Information Resource Centre). Some good examples include garlic, claimed to reduce blood pressure and cholesterol, and green tea, reported to reduce the risk of gastric cancer.

More and more we are seeing the functional properties of foods actively marketed. The boundaries between food and medicine are becoming blurred. Through careful diet selection, foods can offer medicinal qualities, and people are paying more attention to the medicinal properties of food.

So what's this got to do with venison? Well, venison is tender, mild in flavour and can be used year round in a wide variety of culinary styles. These are given, and currently form part of the marketing message used to promote New Zealand venison. Venison is also a functional food. The level of iron absorption for humans is significantly greater when the iron is in haem iron form, and venison has roughly twice the haem iron content of than that of beef or lamb (22 parts per million as apposed to 13 parts per million for lamb and beef loins).

Increasingly, this will become part of the marketing message to specific target audiences. Recognising health is a significant consumer issue, our marketing should not only promote the country of origin, tenderness, versatility and a mild flavour, but promote the healthy properties of venison, being low in fat and cholesterol and high in iron.

\section{Convenience}

A second consumer trend is one towards convenience. Consumers have less time to cook elaborate meals, meaning more ready meals, more heat and eat products and more eating out of the home. People are working more and spending less time at home - and the time that they do spend at home, they do not want to spend in the kitchen.

What does this avoidance of the kitchen signal? Simple, our culinary skills are disappearing, as we rapidly look for easy heat and eat meal solutions. However at the same time consumers expect the best, and do not want to sacrif ice quality. Consumers are effectiv ely saying I $w$ ant a premium product that looks and tastes like it would in a restaurant, but I only want to spend ten minutes preparing it.

The implications for us here are clear, we must provide consumer ready cuts, requiring little or no fabrication and ready meal solutions that exceed quality expectations.

\section{Restaurant consumption}

As consumers ourselves, our inherent laziness doesn't stop with demands for convenience. A third trend we are seeing is that consumers are eating out more. Accor ding to the National Restaurant Association, in the USA alone, the restaurant industry makes sales of $\$ 1.1$ billion each day, with the aver age household spending $\$ 4,500$ each year on food prepared in restaurants.

Consumers are eating out more than ever. How does this affect us as an industry? Restaurants will continue to be an important part of our distribution network. We need to continue to provide the increasingly busy chef with the product he or she needs. And as if chefs w eren't already flat out (those who have seen the Gordon Ramsay 
series on TV will know what I mean!) - restaurants have also entered the home meal replacement market, some offering take home menus, online ordering and drive through windows.

\section{The chef of the future}

So how are chefs coping with all of these changes and additional pressures? Like todays consumers, tomorrows chef will have less and less time to prepare meals. We are already seeing a trend towards more 'chef ready' cuts, resulting in less new, young chefs having the fabrication skills of their more senior counterparts.

It's a fierce world in the kitchen. With increased turnovers, and an ever increasing number of competitors, the chefs of today are also paying more attention to the centre of plate costs than ever before. Chefs not only cook but are now business people as well. Every ingredient on a plate is costed, and must earn its presence on the menu. For a restaurant to include venison on the menu it must be profitable and cannot be labour intensive.

This story illustrates what can be achieved what a chef is given what he needs. Two years ago Graham Brown (Executive Chef, Deer Industry New Zealand) held a chef demonstration at a Dutch cash \& carry outlet. He showed Dutch chefs how tender the leg cuts were, how they could be used in place of the more expensive middle cuts and how New Zealand venison could be used outside of the traditional game season. Recently he repeated the demonstration, and a chef who attended the first demo came up to him and said how he now used leg meat in place of middles. Because he is now buying the less expensive leg meat, and makes a greater margin on the venison dish, he has added two more venison dishes to his menu - and now uses venison out of the game season.

The message here is simple. We must provide chefs with what they want, in terms of product format, and at a price that allows them to make a profit.

Chefs are the gatekeepers of quality for their customers. Their livelihood depends on the experience consumers have in their restaurants. It is in the chef's interest to ensure they use the best possible ingredients.

At product demonstrations for chefs the following questions are always asked:

- What feeds are used?

- Are growth promotants used?

- What age are the animals at slaughter?

- Describe your farming practices.

\section{Future markets}

The next part of this discussion will look at tomorrow's markets, how and where venison will be sold. Historically, New Zealand venison was almost exclusively sold through European Game dealers to the restaurant and manufacturing market.
Today we are seeing a greater emphasis on the retail sector, with efforts to develop year round sales programmes. The retail sectors promote product as farm raised New Zealand venison, distinguishing it from wild European product.

Yet venison must also prove itself to be a profitable line item for retailers to include venison on their shelves year round. Just like a chef needs to know his venison dish must make him a profit, a retailer analyses costs, turnover and the opportunity cost of what other products could be in chiller cabinets.

Retailers also have stringent quality requirements, requiring tracing and auditing of producers, transporters, processors and distributors. Major retailers are not going to risk their international reputation if they have any doubt what so ever over the credibility of a product line. This highlights the importance of quality standards and assurance programmes at every stage of production; on farm, transport, processing and distribution.

\section{Future market opportunities}

The Western European markets, where venison enjoys a privileged place among culinary tradition, are likely to remain key markets. It is within these markets that the greatest immediate oppor tunities are with the retail sector.

But what opportunities lie in other markets? Firstly, the expansion of the European Union likely to include Eastern European countries such as the Czech Republic, Poland, Hungary and the Slovak Republic - we should see growing wealth in these markets, all with a history of consuming venison. Already, good opportunities are being discovered in their urban centres, primarily through the tourism market.

Any discussion on tomorrow's markets would be foolish to omit China. With a population of 1.3 billion, and year on year growth of between 7 and $8 \%$, China is already the world's second largest economy and likely to offer some good, albeit long term opportunities.

\section{Summary}

This paper discusses current trends and market opportunities. To capitalise on these opportunities, we as an industry need to remain focused, and our direction needs to be taken from the market. We must provide the consumer with what he or she wants. Consumers are demanding healthy products, and they want convenient, premium quality products.

We must listen to their concerns. Consumers are showing greater interest in issues like animal welfare, not only must our products meet all taste and tenderness expectations, but production methods also need to meet certain standards and expectations.

Our focus is clear. We are already seeing greater emphasis placed on retail development. At a recent food 
fair that we attended, not one meeting passed without the importer stressing our direction needs to be through retail development. We must also continue to differentiate New Zealand farm raised venison from wild venison, and promote year round usage. Underpinning the development of 12 month sales programmes for the retail sector is product development, and we must ensure we are providing what the consumer is demanding.

Table1 Mean iron concentration (ppm) of venison loin compared with meat of other species.

\begin{tabular}{|c|c|c|c|c|c|c|c|}
\hline Species & \multirow{2}{*}{$\begin{array}{l}\text { Venison } \\
\text { Loin }\end{array}$} & \multicolumn{3}{|c|}{$\begin{array}{l}\text { Sheep meat } \\
\text { (rams and hoggets) }\end{array}$} & \multicolumn{3}{|c|}{$\begin{array}{c}\text { Beef } \\
\text { (heifers) }\end{array}$} \\
\hline Muscle & & Loin & Leg & Shoulder & Loin & Leg & Shoulder \\
\hline Soluble haem & 18.5 & 9.53 & 5.67 & 8.14 & 11.69 & 9.78 & 13.59 \\
\hline Insoluble haem & 3.6 & 3.83 & 1.69 & 2.83 & 1.91 & 1.98 & 2.4 \\
\hline Total haem & 22.1 & 13.36 & 10.52 & 15.84 & 13.6 & 11.77 & 15.99 \\
\hline Soluble nonhaem & 1.8 & 1.38 & 1.06 & 1.52 & 1.31 & 1.36 & 1.35 \\
\hline Insoluble nonhaem & 5.1 & 2.76 & 2.35 & 2.73 & 1.36 & 1.49 & 1.93 \\
\hline Total nonhaem & 6.9 & 4.14 & 3.4 & 4.25 & 2.67 & 2.85 & 3.28 \\
\hline Total Iron & 27.5 & 17.5 & 13.92 & 20.09 & 16.27 & 14.61 & 19.28 \\
\hline
\end{tabular}

Figure 1 Requirements for increased venison sales in traditional and future markets.

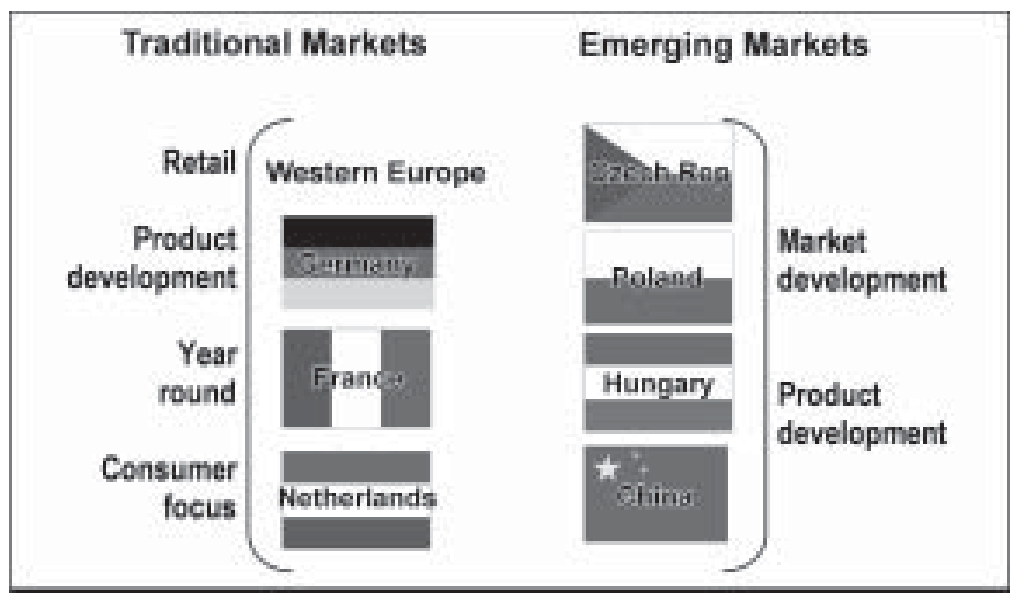

